\title{
The Role of the Federal University of Technology, Akure Cooperative Multipurpose Society in Housing Finance
}

\author{
Ojo B. ${ }^{1, *}$ and Rotowa O. O. ${ }^{2}$ \\ ${ }^{1}$ Department of Estate Management, Federal University of Technology, Akure, Nigeria \\ ${ }^{2}$ Department of Urban and Regional Planning, Federal University of Technology, Akure, Nigeria \\ Corresponding Author: *bojo@ futa.edu.ng
}

\begin{abstract}
Housing finance in Nigeria is facing a lot of problems among which are inadequate mortgage finance, inaccessibility to other form offormal loans from other financial institutions due to stringent conditions attached to its access; urbanization brought about by ever increasing human population; and the economic recession being experienced in Nigeria. Housing development financing and shelter provision among the low and medium income groups become more critical because of lack of access to credit; and these groups constitute the vast majority of the urban households in Nigeria. There are no robust and pragmatic housing finance systems on ground. The reality on ground led to evolution of informal housing finance system of which thrift and credit cooperative is one. Against this background the paper examine the role played by the Federal University of Technology, Akure cooperative multi-purpose society in the provision of housing finance to its members, Secondary data were collected for this study through the use of structured questionnaire from $29.5 \%$ of its members. Secondary data were equally obtained from archival data of the society and analysed. The study revealed that majority of their members relied on collection of loans from the cooperative society for their housing development finance. The preferences for this form of finance were given as: ease of processing loan application; low interest rate charge on loan; and ease of amortization. The paper posits that government should intervene in housing finance through methods such as site and service scheme, provision of low interest loans with longer moratorium periods, and special political consideration and leverage be given to the housing need of low and medium income earners to ameliorate poverty among this group.
\end{abstract}

Keywords: Housing finance, Cooperative society, Low and medium income, Member

\subsection{Introduction}

Housing problem in Nigeria is diverse and complex, manifesting in the form of overcrowding, homelessness, substandard housing, slum and squatter developments. The quality and quantity of housing in Nigeria is inadequate when compared with the population. It is reported in literature that housing deficit in the country was estimated as 8 million in 1991 and between 12 and 14 million in 2007 (Olujimi, Bello, Fasina, Ojo and Rotowa, 2013). Hence, about N35 trillion would be required to fund such deficit (Olujimi et. al., 2013). Problems associated with housing in Nigeria are high rent in the housing market, inadequate mortgage financing and inaccessibility to mortgage loans (Aribigbola, 2012). The housing situation is getting worse because of population increase, urbanization, industrialization, economic recession and inadequate general prosperity, lack of access to sources of funding. The availability of proper and adequate housing development finance is pivotal to an effective and sustainable shelter provision. Lack of access to suitable form of credit has always been a major obstacle to the provision of shelter for the low-income groups, which constitute the vast majority of the urban households in developing countries.

The housing sector plays a critical role in the welfare of the citizens of a country as it directly affects not only the well-being of the citizenry but also the performance of other sectors of the economy (Sanusi, 2003). Housing development finance is pivotal to shelter provisions and is very important due to the following reasons. First, it is one of the three most important basic needs of mankind, the others being food and clothing. Second, housing is a very important durable consumer item, which impacts positively on productivity, as decent housing significantly increases workers' health and well-being. 
Third, it is one of the indices for measuring the standard of living of people across societies. Investment in housing necessitates the perceived or imagined pecuniary or non-pecuniary benefits. Such benefits varies according to the aspiration of the investor. Invariably, such gain might be financial, prestige, privacy, or security. Consequently, greater attention is needed in the recognition of the critical importance of financing housing delivery system.

The focus of finance has been very prominent for obvious reasons. This is because housing provision requires a huge capital outlay which is often beyond the capacity of the medium/low income groups. A major area of concern is that most of the institutional sources of housing finance are often inaccessible to most Nigerian households, especially low-income earners (Olufemi, 1993; Onibokun, 1985; Falegan, 1985; Olatoye, 2005). Experts' projection of the population having decent houses does not bring immediate succour as most see the situation as likely to worsen. A shelter provision gap exists in Nigerian because its population growth rate of about three point eight per cent (3.8\%) annually, is not been matched by a corresponding increase in home ownership (Adegboye, 2004). The federal government is aware of this, hence the setting up of the presidential Technical Board of the Federal Mortgage Bank of Nigeria whose chairman, Professor Akin Mabogunje posits that "without mortgage finance, the average worker cannot own a house.

The failure of the formal housing development finance institutions in Nigeria to adequately address the need of the vast majority in the area of home ownership led to the evolution and existence housing finance system of which also include thrift and credit (World Bank, 1982). The pertinent questions are thus: how does the low income and medium income earners cope with sourcing for finance for home ownership? What are the strategies adopted? What are the requirements of these non-conventional methods of housing finance and what is the level of patronage? What are its effectiveness and limitations? Hence, this paper will evaluate the contribution of Federal University of Technology, Academic Staff Cooperative Society (FUTASCOOP) in the provision of home ownership among its members. The problems highlighted above, has been particularly identified with developing countries and the impact of the informal institutions for housing development finance cannot be properly quantified because they are largely uncoordinated, scattered and varied in scope and operational depth.

In Nigeria, methods adopted for housing financing before and during the colonial era include village development scheme, social club contributions, and loans from traditional setting. These methods are now replaced with modern ones to reflect the growing complexities emerging in the economic sectors; these methods can be classified into the formal and the informal sectors (Nubi, 2000). The formal sector operates within statutory guidelines provided by the federal government. Major players are the Federal Mortgage Bank of Nigeria Finances, commercial Banks, Specialised Development Banks, Insurance Companies and Pension/Provident Funds. On the other hand, the informal sector is dominated by individual money lenders, voluntary savings, personal or family savings and Cooperative Societies. However they are gradually becoming unreliable because of the low propensity to save. This is further exacerbated by bank and liquidation of banks and non-compensation of affected people.

Similarly, the gap between income and shelter cost in Nigeria is very wide. The low-income earners are completely eliminated from the housing market. This is attributed to high cost of building materials, astronomical inflationary rate in the economy, excessive fees demanded for by the professionals involved in housing finance and excessive profit of contractors (Windapo, 2000 and Okupe, 2000). Olatoye, (2005) noted that financing the real estate investment has in recent time become more problematic due to the complex interaction of several factors. Among these are high interest rates charged on loans, stringent repayment requirements, and almost impossible prequalification conditions imposed by lenders. The bulkiness and illiquid nature of real estate investment poses serious challenges in the uncertainty bedevilling the economy. In the housing sector, these problems are what culminate in high cost of housing delivery and lack of access to home ownership by a large section of the population that are in most need.

Nigeria is yet to develop a robust and pragmatic housing finance system. The level of operation is still at depository level and other traditional methods of housing finance characterized by absence of appropriate legal framework for housing development finance through functional mortgage and capital markets. In Nigeria, it has been difficult for owner occupier to finance their residential property development without resulting to a source of pooling capital together through cooperative efforts. This can be attributed to lack of well-developed mortgage market operation, lack of involvement of capital 
market financing of real estate development and an enabling environment for operation. It is therefore imperative that alternative funding approaches that can eliminate or at least mitigate the difficulties hitherto experienced in conventional housing finance be examined. There is the need to study the modus operandi (mode of operation), and the contribution of the cooperative society to home ownership among the working class since it is as alternative option open to them.

The International Cooperative Association (ICA) defined a cooperative society is an autonomous association of persons united voluntarily to meet their common economic, social, and cultural needs and aspirations through a jointly owned and democratically controlled enterprise. A cooperative has been defined as a user-controlled business that distributes benefits on the basis of use (USDA, 1987). They are usually organized as a social association but with more commitment to financial activities of individuals and the collective interest of their members. They emerged because of prevailing social needs in Nigeria. Presently, the country is undergoing economic recession, which has reduced the purchasing ability of an average Nigerian. The cooperative societies have effective methods of generating funds from within and outside membership. Hence, they are good sources of fund generation which could be channelled to housing project and loans that could be diverted to house building. Olujimi et al (2013) outlined the benefits of cooperative societies to include: access to quality supplies and services at reasonable cost; increased clout in the marketplace; share in the earning of cooperative business; enhancement and protection of local economy; and provision of monetary loan for reinvestment into many sectors such as housing.

In addition, some cooperative society build houses for members on rotation, otherwise, own housing estates. The two prominent cited by Reis in Adedeji and Olotuah, (2012) are Ibadan Cooperative Thrift and Credit Union (CTCU) and Owolowo Union. The authors equally mentioned Owo Multi-purpose Cooperatives, Credit Thrift Cooperative Society in Ondo State that facilitated housing ownership by members. Assistance was rendered in areas of acquisition of land, material purchase and processing of documents. The eight registered cooperative societies operating presently in the Federal University of Technology, Akure (FUTA) are: FUTA Housing Corporation; Senior Staff Association; Women's Club Society; Association of Staff Union Cooperative Society; Federal University of Technology Akure Academic Staff Multi-Purpose Cooperative societies; God-favour Cooperative Society; Equipment Maintenance Centre Cooperative; and FUTA Primary Staff Cooperative Society. As could be observed, the services rendered by the cooperatives can be predicted by their names. Areas of specialities of these societies include rental services, funding of property development schemes and home ownership schemes. FUTAASCOOP the focal point of this study made impressive profits for the past three years as published in the annual report for 2014 to 2016. The study seeks to examine the role of the Federal University of Technology, Academic Staff Cooperative Society (FUTASCOOP) in providing finance of housing project to its members.

\subsection{Research Methodology}

The study was carried out among members of the Federal University of Technology Akure Academic Staff Multi-Purpose Cooperative societies (FUTAASCOOP) in Nigeria. The Federal University of Technology Akure (FUTA) is located on Latitudes $5^{\circ} 45^{\prime}$ and $8^{0} 15^{\prime}$ North of equator and Longitudes $4^{0} 30^{\prime}$ and $6^{0}$ East of Greenwich Meridian. The aim of FUTAASCOOP are : to promote the spirit of cooperative among academic staff members; to enhance the socio-economic well-being of members through investment in viable projects; to create a pool of fund for lending purposes to members and to provide opportunities for members for thrift savings. Others include arranging regular bulk purchase of essential commodities as and when necessary; provision of goods and services to members at reasonable cost and; to organize regular membership education.

FUTAASCOOP has about 677 members from which, a selected sample of two hundred (200) staff members amounting to about $29.5 \%$ were chosen for questionnaire administration. Data were obtained by questionnaire administration, direct observation and facility survey. There are eight registered cooperative societies in FUTA, which are representatives of cooperatives societies involved in housing finance in tertiary institutions in Nigeria. Secondary data, involving staff records and administration of housing finance were sourced from the Human Resources Department and various cooperative societies in the institution. A total number of one hundred and eighty five (185) questionnaire consisting $92.5 \%$ were retrieved for analysis. A set of questionnaire was administered on respondents who were 
Academic members of the Society. The questions contained in the questionnaire were on the amount of loans obtained and modalities of payment; other sources of housing finance apart from the cooperative society and; reasons for choosing a Cooperative loan for housing development.

\subsection{Results and Discussion}

The financial performance of FUTAASCOOP is presented in Table 1. From a cursory look at table 1, it could be deduced that there is an increasing interest from members. It was observed that there was a rising trend in membership from 547 in 2013 to 677 in 2015. Equally, membership savings and share capital was on the increase during the period. The savings from the audited account reveals an increase from $\$ 473,067,411$ (Nigerian Naira) to $\$ 713,792,786.59$ Naira within the three year period. This reveals that the cooperative is viable. This was corroborated by the balance sheet where there was a surplus of $\$ 59,070,169.20$. Loanable fund for statutory activities will not be a problem in the cooperative society.

Table 1: Three years Annual Report 2014 to 2016 (Source: Audited Account of the $13^{\text {th }}$ Annual General Meeting FUTASCOOP)

\begin{tabular}{|c|c|c|c|}
\hline & December 2013 & December 2014 & December 2015 \\
\hline Membership & 547 & 585 & 677 \\
\hline Membership saving & $\$ 473,067,411.89$ & N592,936,928.60 & $\$ 713,792,786.59$ \\
\hline Share Capital & 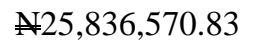 & $\mathrm{N} 25,585,861.93$ & $\mathrm{~N} 26,240,368.21$ \\
\hline
\end{tabular}

\subsection{Age of Respondents}

Membership modal age of this cooperative is between 36 to 59 years, these constitute about $43.8 \%$ of respondents in the study. The age cohort from 51 to 60 were next in proportion, they account for $34 \%$ of respondents. The third age group that was revealed by the study were those below 35 years, while the last age group were those who were about to retire they were between age 60 and above. This implies that majority of respondents were in age brackets where they are either planning to build or are building.

Table 2: Age of Respondents (Source: Authors' Fieldwork, 2016)

\begin{tabular}{lcc}
\hline Age Group (Years) & Frequency & Percentage (\%) \\
\hline Below 35 & 22 & 11.9 \\
$36-50$ & 81 & 43.8 \\
$51-60$ & 63 & 34 \\
Above 60 & 19 & 10.3 \\
Total & $\mathbf{1 8 5}$ & $\mathbf{1 0 0}$ \\
\hline
\end{tabular}

\subsection{Amount of Loans Obtained}

Table 3 reveals that majority of respondents interviewed collected loans ranging from $\$ 300,000$ to $\$ 500,000$ (56.8\%). This was followed by respondents that collect loans from $\$ 500,000$ to $\$ 1$, 000,000 . The proportion of respondents that collects loans below $\$ 300,000$ were $13.6 \%$, while $10.7 \%$ collected loans above $\$ 1,000,000$. This implies that most of the respondents will not be able to complete their building project within one calendar year. This can be attributed to low propensity to save and high cost of houses in government housing schemes. For example, Adedeji \& Olotuah (2012) submits that 2-bedroom at Michael Otedola, Jubilee Housing scheme cost about $\$ 300,000$. In other housing estates, cost of completed houses range between $\$ 750,000$ in Owotu Housing estate to more than One million naira at MKO Gardens in Lagos. In Akure, the cost of a completed bungalow at Ibule Housing scheme was about Three million naira. Residents of Akure could not purchase these buildings until the Federal University of Technology, Akure, bought the estate. 
Table 3: Amount of Loans Obtained (Source: Authors' Fieldwork, 2016)

\begin{tabular}{lcc}
\hline Loans Obtained (Naira) & Frequency & Percentage $(\boldsymbol{\%})$ \\
\hline$<300,000$ & 25 & 13.6 \\
$301,000-500,000$ & 105 & 56.8 \\
$501,000-1,000,000$ & 35 & 18.9 \\
$>1,000,000$ & 20 & 10.7 \\
\hline
\end{tabular}

\subsection{Sources of Housing Finance for Respondents}

The sources of financing housing project as attested to by respondents were: personal savings, bank loans, cooperative society (FUTAASCOOP), and other sources. It was observed that $93.1 \%$ of respondents financed part of their housing project from loans obtained from the cooperative society. This implies a high patronage and reliance on the ability of the cooperative society to provide requisite fund when co-operators meet requirements.

Table 4: Sources of Housing Finance for Respondents (Source: Authors' Fieldwork, 2016)

\begin{tabular}{lcc}
\hline Source & Frequency & Percentage (\%) \\
\hline Personal Savings & 8 & 4.2 \\
Bank Loans & 4 & 2.3 \\
FUTAASCOOP & 172 & 93.1 \\
Others & 1 & 1.7 \\
Total & $\mathbf{1 8 5}$ & $\mathbf{1 0 0}$ \\
\hline
\end{tabular}

\subsection{Reasons for choice of cooperative loans for Housing Development}

In general, people look for loans from sources that charges low interest rate. This determines their ability to amortize such loans. Presently in Nigeria, the depressed economy makes take-home pay very small, as money spent on other purposes outside housing takes a great proportion of salaries and wages. At an exchange rate of $\$ 1=\mathrm{N} 367$, the minimum wage of $\mathrm{N} 18,000$ is just about $\$ 50$. Therefore, the purchasing power of an average Nigerian is below the $\$ 1.25$ level of absolute poverty. Table 5 presented the reasons for patronizing a cooperative society for loans. Close to one third of respondents $(32.97 \%)$ say they patronize the cooperative society because of ease of processing loan application. In addition, about a fourth of respondents $(24.87 \%)$ submit that low interest on loans attracted them to the cooperative society. Another one fourth of respondents $(24.32 \%)$ reports that the reason for applying for a cooperative loan is due to timeliness/promptness of granting the loan. The study reveals that only about a fifth of respondents (17.84\%) patronize the cooperative because of ease of repayment of loans collected. Aggregating the reasons for choosing cooperative for housing loan reveals that housing loans are pecuniary, the purchasing power of respondents will not support them looking for loans from financial institutions.

Table 5: Reasons for choice of cooperative loans for Housing Development (Source: Authors' Fieldwork, 2016)

\begin{tabular}{lcc}
\hline & Frequency & Percentage (\%) \\
\hline Ease of processing of application & 61 & 32.97 \\
Low interest on loan & 46 & 24.87 \\
Timeliness of granting the loan & 45 & 24.32 \\
Ease of repayment of loans by respondent & 33 & 17.84 \\
Total & $\mathbf{1 8 5}$ & $\mathbf{1 0 0}$ \\
\hline
\end{tabular}




\subsection{Conclusion}

The paper addresses the financing of housing projects by FUTAASCOOP cooperative society at the Federal University of Technology, Akure. This is in a view to discover how low-income people in developing countries circumvent financial and mortgage institutions to finance housing projects. The paper shows that the people interviewed were economically disadvantageous due to economic recession and low Naira to Dollar ratio. It was revealed that credit societies have provided housing finance to a substantial number of their members, enabling them to become home-owners.

The funds received most of the time were not the only source of funding the building projects. This was due to unstable and high cost of building materials. The proportion of people involved in cooperative societies is still infinitesimal when placed side-by-side with the wider population that are not cooperative members. Therefore, housing low-income earners is still a problem in Nigeria, in term of funding housing projects.

The paper posits that government should intervene in housing finance through methods such as: site and service scheme, provision of low interest loans coupled with long moratorium enabling the people to pay for a long time. When the housing need of low and medium income earners are met, poverty would have been ameliorated, and the people can concentrate on other profitable ventures.

\section{References}

Adedeji, Y. M. D. and, \& Olotuah, A. O. (2012).An evaluation of accessibility of Low-income earners to housing finance in Nigeria. European Scientific Journal, 8(12), 80-95.

Adegboye, K. (2004, December 21). Mabogunje x-rays new housing finance policies at FMBN Forum. Vanguard Online. Lagos.

Aribigbola, A. (2012). Sites - and - services as a strategy for achieving adequate housing in Nigeria inthe 21 st Century, 2(2), 126-132.

Falegan, S. B. (1985). Housing finance and finding: The Nigerian experience. In O. P. (ed) (Ed.), Housing in Nigeria. Ibadan: NISER.

Nubi, T. O. (2000). Housing finance in Nigeria- need for re-engineering. Ideal Habitat Cooperative Housing Initiative. Available on www.housefinance.org/pdfstorage/Africa. Accessed 15 September 2014.

Ojeme, V. (2004). Securitization and real estate investment in Nigeria. Vangard Newspaper online athttps://www.vanguardngr.com. Accessed 31 August2004.

Okupe, L. (2000). The Role of Private Sector in Nigeria. In NISER (Ed.), A seminar paper on Effective Approach to Housing Delivery in Nigeria. Ibadan: NISER.

Olatoye, O. (2005). Borrowers' perception of the degree of cumbersomness of lenders requirements in housing financing in South western Nigeria. In S. A.C. (Ed.), The Quennsland University of Technology, Research Week International Conference Proceeding. Brisbane, Australia: Sidwell A. C.

Olufemi, O. A. (1993). Institutional Housing finance in Nigeria: A case study of the study of the Property Development Corporation of Oyo State. In Monograph No 6, NISER, Ibadan.

Olujimi, J.A.B., Bello, M.A., Fasina, O.O., Ojo, B., and Rotowa, O. O. (2013). Assessment of cooperative societies as source of financing housing provision in Akure, Nigeria. Akure.

Onibokun, P. (1985). Housing finance in Nigeria: A critical survey of private and public sources. In P. Onibokun (Ed.), Housing in Nigeria. Ibadan: NISER.

Sanusi, J. O. (2003). Mortgage financing in Nigeria: issues and challenges. In 9th John Wood Ekpenyong Memorial lecture. Lagos: Nigerian Institution of Estate Surveyors and valuers.

Windapo, A. (2000). Constraints of construction industry in an unstable economy. In Effective Approach to Housing Delivered in Nigeria organized by the Nigerian Institute of Building, Ibadan. 